УДК 373.3.016:811.111]:004.738.5

DOI: http://dx.doi.org/10.30970/vpe.2018.33.9963

\title{
USE OF INFORMATION AND COMMUNICATION TECHNOLOGIES IN ENGLISH LANGUAGE TEACHING AT PRIMARY SCHOOL
}

\author{
Olena Lushchynska \\ Ivan Franko National University of Lviv, \\ Tuhan-Baranovskoho Str., 7, Lviv, Ukraine, UA-79005 \\ We have modified our environment so radically that we must now modify ourselves to exist in \\ this new environment \\ Norbert Wiener, American scientist, mathematician and philosopher
}

The article is devoted to the description of theoretical and practical aspects of ICT use in the English language teaching at primary school. In the introduction the authors outline the relevance of the investigated problem, and determine the contradictory aspects of the educational process organization in the primary school, that do not ensure the proper use of information and communication technologies in the work of the primary school teacher.

The set purpose of the article is to analyze the possibilities of the information and communication technologies using in the process of English language studying by the primary school students. It is disclosed through the cumulative selection of materials and methods of presentation (analysis of the theoretical scientific studies of domestic and foreign researchers, empirical study of the information and communication technologies use by the primary school teachers and interpretation of the results, visualization of the theoretical and methodological materials of the research, specification of the Internet services, systematic analysis of the comprehensive study of the identified problem).

The article clearly describes the Internet services, offered by the authors for the study of a foreign language by the primary school students (You Tube, English Language Teaching Resources, Kids' Pages, ESL-Kids, Games to Learn English, iSLCOLLECTIVE, ESLvideo, Agenda Web, Tools for educators, Web2.0 Learning Apps. Org, Loupe); it is indicated that the information and communication technologies use in the foreign language learning is of great practical importance (the article specifies the opportunities that are implemented in the educational process of the primary school).

The defined conclusion and prospects of the study show the logical connection of the identified problem with the subsequent scientific researches, determine the organic combination of theoretical achievements with the necessity to find ways for their practical application.

Key words: information and communication technologies, English language, primary school students.

(C) Lushchynska O., 2018 
At the present stage of the educational branch modernization and reforming, selection of the newest forms, methods and means of teaching and upbringing of the primary school students is the relevant problem of studying process organization. Primary school students do not show a high level of activity in the process of learning in general and English studying in particular. It is important for the teacher in the modern world of information to move with the times. Since, children who are developing with all gadgets and have access not only to games, but also to other modern means of information transferring, become passive to the process of obtaining information that is transmitted by so-called outdate, "strange" to them forms and means. Taking this into account one of the problems of lack of motivation to study at the primary level of education is not the informatization of all branches of society, but the partial lack of information and communication technologies application in the process of foreign language competence formation of the primary school students.

Information and communication technologies (ICT) are the leading and indispensable means for the functioning of many processes in all areas of society's life. The advanced computer skills are not a requirement but a necessity. To be a competitive professional in your business, you need to change yourself, work and improve all the time. Certainly, it's difficult to research and master all modern information and communication technologies as they are constantly changing and updating. However, you need to be able to use modern ICT, especially if you are a teacher $[1$, p. 73$]$.

In the process of online survey, where 35 teachers of primary schools in Lviv, Kamyanets-Podilsky, Glukhov were involved (Fig. 1), analysis of the results showed that only 2 participants use the computer once a week, and to the question: Should the computer be used in the primary school? all respondents answered affirmatively, which makes it possible to confirm that teachers are ready to use ICT. However, to the question: How and how often teachers use ICT?, most respondents answered: for video demonstration, presentations and for the preparation of the didactic materials in a text editor, etc. Mostly teachers use ICT: to find the necessary information (23 respondents), to communicate with colleagues (16 respondents), to develop the didactic material (23 respondents), to select audio and video materials (26 respondents), to create a presentation to the lesson ( 22 respondents), channel, blog, site ( 2 respondents). The results show that primary school teachers do not use all the possibilities of information and communication technologies, but only part of them. 


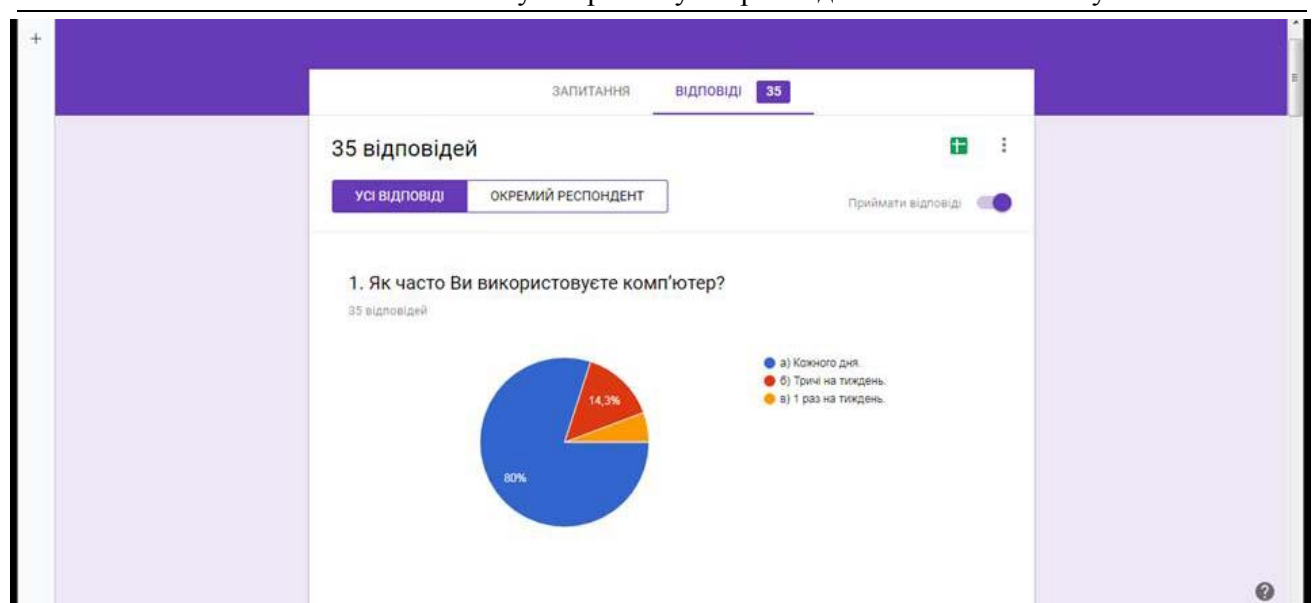

Figure1. A fragment of the survey results, which has been made with a help of Google forms

In our opinion, the main reasons of the passive attitude of teachers to ICT are the following: the fear of doing something wrong, the lack of desire to learn something new, improve the traditional forms, methods and means of studying organization in the primary school [2].

Taking this into account, we consider that it is necessary to make an analysis of possible ways of information and communication technologies using in the process of English studying by the primary school students.

The theoretical processing of this problem makes it possible to argue that the implementation of information and communication technologies in the educational process and the training of future teachers remains an urgent problem which has been researching by scientists V. Bykov, G. Vorobiev, G. Vorontsova, L. Kovalchuk, G. Plakhotnyuk, I. Prokopenko, O. Pochupailo, N. Fominykh, L. Chernysh, N. Shykh, O. Yuzyk and others.

The formation of skills to use the information and communication technologies in the educational process was discussed in the works of $R$. Hurevych, S. Gunko, M. Zhaldak, A. Kolomiets, M. Kademiia, Yu. Mashbytsa, N. Morse, E. Polat, I. Robert, Yu Tryus, S. Khrystochevskyi and others. Influence of information and communication technologies on the content and methods of studying was researched by N. Apatova, V. Klochko.

The significant scientific contribution to the method of computers using in the educational process is presented by N. Balyk, R. Williams, O. Hokun, C. McLean, N. Morse, V. Kaimin, K. Osadcha, V. Osadchyi, Yu. Ramskyi. Special attention is devoted to the use of Internet technologies in the educational process (V. Bykov, O. Glazunova, R. Hurevych, L. Doliner, I. Zakharov, N. Morse, K. 
Obukhova, V. Osadchyi, E. Patarakin, E. Polat, T. Punina, I. Robert, A. Tikhonova, G. Stetsenko).

Many of the domestic and foreign scientists describe the subject of information and communication technologies usage in the process of foreign languages studying (E. Azimova, V. Afanasiev, I. Bloshchynskyi, L. Boykiv, N. Borysko, Yu. Verysokin, M. Yevstyhnieiev, N. Kalynenko, O. Kazachiner, G. Lazaruk, M. Morska, E. Polat, T. Oliinyk, O. Safonova, T. Svirepchuk, I. Stepanchenko, P. Sysoev, A. Taushan, S. Titova, N. Fominykh, V. Chumak, I. Yaremchuk, A. Bruns, P. Duffy, J. Reinhardt, G. Stanley, R. Stannard, SL Thorne, E. Tonkin).

The purpose of the article is to analyze the possibilities of information and communication technologies usage in the process of English studying by the primary school students.

In order to solve the problems we used the complex of theoretical (the analysis and the synthesis of psychological and pedagogical, scientific and methodological literature, a comparison of theoretical positions of researchers to the identified problem) and empirical (qualitative and quantitative analyses of the obtained results, methods of mathematical statistics) of the research methods.

For studying the problem of using information and communication technologies primary school teachers used an observation, a survey, a definition of level, a frequency, the ways of using ICT; a questionnaire for studying the problems of using ICT in the educational process. The verification of the effectiveness of the proposed ICTs is carried out in the process of observing, questioning and practical activities of Lushchynska O.V. in the learning process for elementary school students.

Nowadays education should substantially update the content of foreign languages teaching, and introduce new means of formation of foreign language professional and communicative competence of future specialists who will have the educational and life substantiation, and the success of the competence formation will depend on the activity of those who study [3].

M. Kademiia indicates that the insufficient use of information technologies is generally related to the low level of information culture (IC) of society, nonacquaintance of the wide possibilities of the information technologies using, weak motivation of teachers, students and pupils to use information technologies in the educational process and professional activity [4, p. 12].

The society is rapidly developing and using means of communication technologies, mobile satellite communication technologies, the Internet, etc., which led to the development of mobile communication and related information technologies. This enabled us to obtain knowledge with a help of mobile phones, pocket personal computers, laptops, netbooks, tablets, etc. 
ISSN 2078-5526. Вісник Львівського університету. Серія педагогічна. 2018. Випуск 33

The use of information and communication technologies enables the teacher to create an informational and didactic environment in the process of foreign language studying by the primary school students. However, the level of ICT use depends, first of all, on teachers' professional training, awareness and readiness for active use in the process of foreign language competences formation of the primary school students. Information technology is a set of methods and software, hardware means, combined into the technological chain, which provides collecting, processing, storing and displaying of the information in order to reduce the complexity of its use, as well as to improve the reliability and efficiency of the educational process $[4$, p. 9].

The material basis of information technologies is the technical means that use the appropriate software products, with a help of which the collection, storage, transmission and processing of information are implemented. A personal computer, filled with a set of peripheral devices is the main means of information technologies, which is used in the industrial education. Universal office applications and means of information and communication technologies were widely distributed in the education system, such as word processors, spreadsheets, presentation programs, database management system, organizers, graphic packages, etc. The development of computer networks helped users to receive a new opportunity to get a quick access to various information through the global telecommunication network Internet, as well as possible instant access to the world information resources [5, p. 39].

$V$. Chumak highlights the following areas of ICT use at English lessons:

- Internet;

- CDs for practical work, project, essay writing;

- a lesson with the use of multimedia capabilities of the computer, which serves as a visual guide;

- the creative task [6].

The use of information and communication technologies enables to provide the educational process with qualitative didactic materials, contributes to the formation of a high level of motivation for the study of the primary school students. Nowadays students are surrounded by information and telecommunication technologies. Therefore, a student can not remain a passive observer or an unconcerned performer. Taking this into account, we propose the following ways of ICT using in the process of foreign language competences acquisition by the junior pupils:

- using of the standard programs (text editor, presentation editor, editor of publications) for the establishment of the didactic materials;

- using of the social services for the communication with parents, colleagues; 
- using of Web technologies for the establishment of didactic materials, interactive exercises, tests, video materials, books for reading;

- using of Web sites, portals, pages with free content for a foreign language studying.

We will pay attention at each of the ways of ICT using.

I. Using of the standard programs (text editor, presentation editor, editor of publications) for the establishment of didactic materials

Standard programs help the teacher to develop large and small visual dictionaries, stickers, materials for motivation (bonuses, fairy money, certificates, masks for communication exercises, exercises, dominoes, cards for games, etc.) (Fig. 2). The resources, developed by us, are published on the website of Ivan Franko National University of Lviv (http://pedagogy.lnu.edu.ua/english).

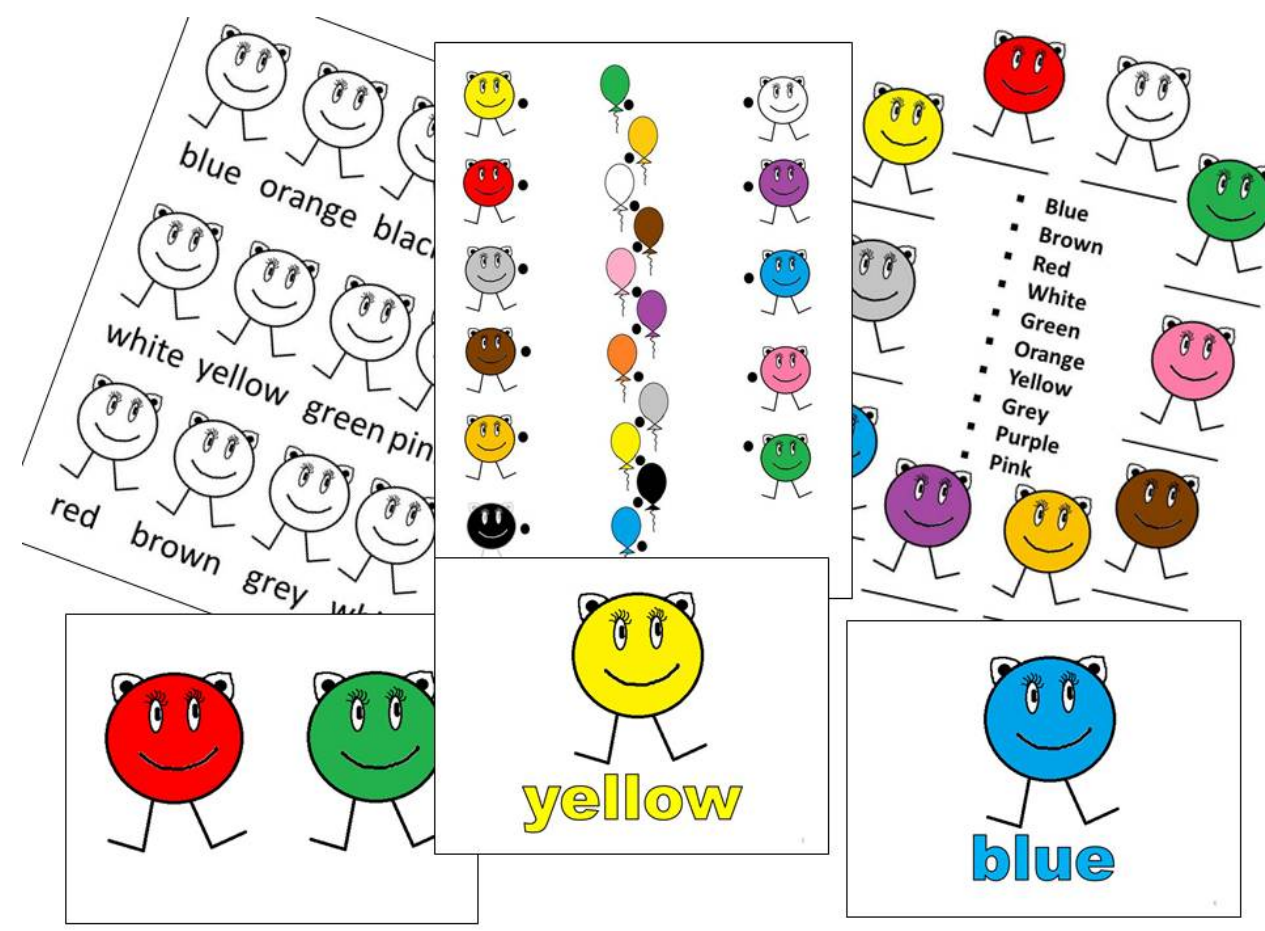

Figure. 2. Author's exercises designed with a help of the presentation editor

Possibilities of the presentation editor, a text editor in the process of English practicing and teaching (Fig. 3):

- Visual dictionaries formation.

- Creation of the cards for the didactic material repetition and consolidation. 
- Small visual dictionaries formation.

- Mobile dictionaries formation (a word appears on the slide, and the students encircle it).

- Exercises creation.

- Didactic material creation (posters, motivational items).

- Creation of video presentation.

- Creation of presentation.

- Students involving in the use of the editor of publications (business cards, calendar, bookmarks, advertising in English) presentations, a text editor in the process of personal projects creation.
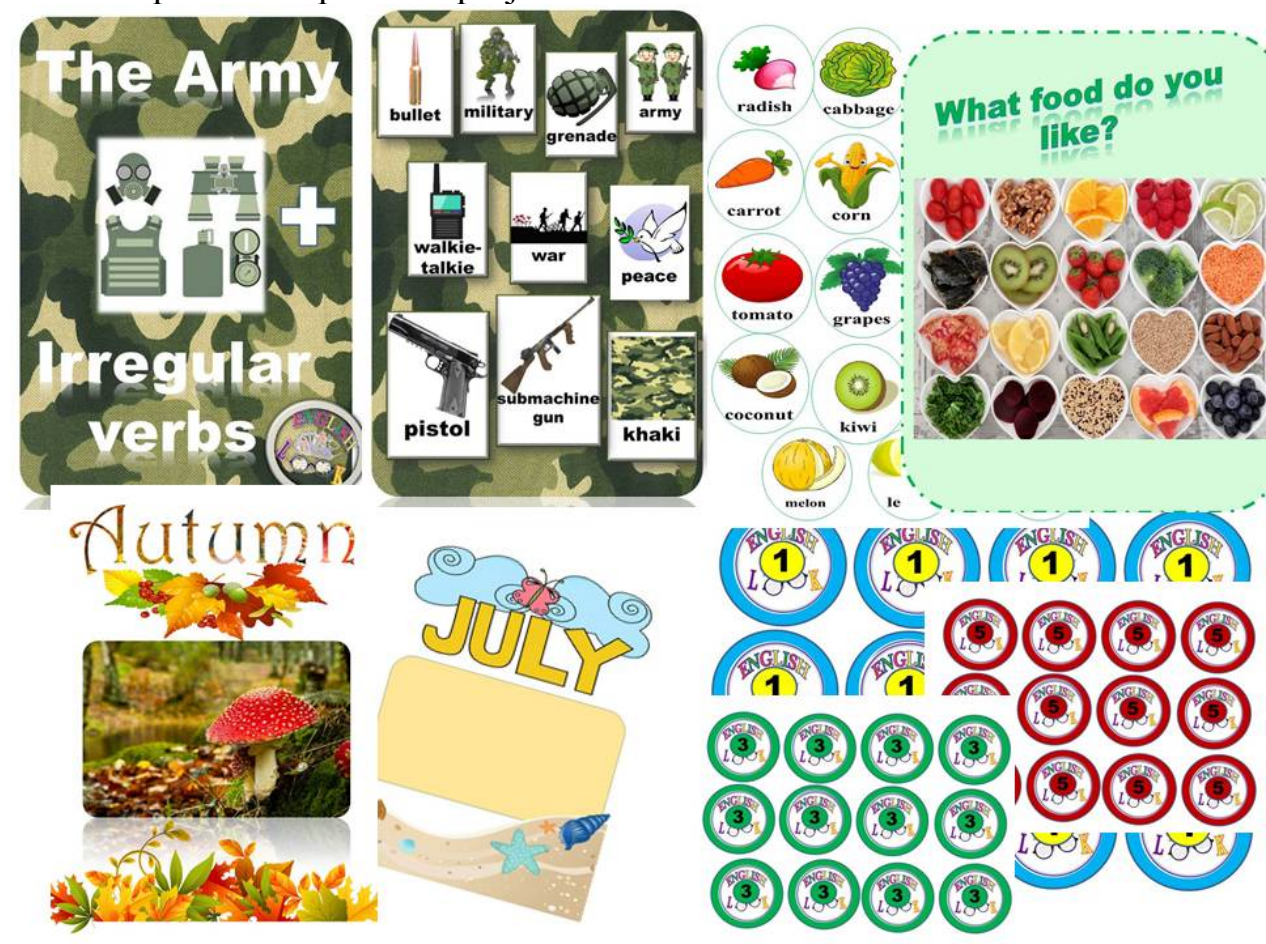

Figure.3. Examples of bonuses, visual dictionaries and other didactic materials

\section{colleagues.}

II. Using of social services for the communication with parents,

Social services are getting enormously popular among the members of the school community. Teachers, parents, and students are involved in the virtual communication, discussion and solving of some specific issues remotely. Teachers actively share thoughts, projects and didactic materials with colleagues. In many social services there are enormous communities of teachers, parents and students who, through the mutual communication, share materials, ideas and thoughts. We 
will take into account the most successful social services, which are becoming popular among the teachers, parents and students:

Twitter - a social microblogging network which allows users to send short text messages with a help of the Web interface.

Google - the largest search system, which provides many additional services, and combines a large number of useful resources, in particular: Gmail, Google Sidewiki, Google Drive, Google Calendar, Page Creator, Google Maps, Google Earth, Google Docs, Google Chrome etc.

Google + - multilingual social network and identification service, was founded in June 2011, the second largest, after Twitter, has about 500 million registered users.

Google Translate - online service of Google company, which allows you to translate words, phrases, sentences, texts and Web pages (80 languages to the user's choice).

Lingvo - online service, which helps to translate words and phrases into 20 foreign languages. For English, Lingvo offers over 50 modern dictionaries on different topics.

Systranet - online translation service, founded by the American company Systran. Online translation of the materials of this service supports 15 languages.

Wikipedia - an open multilingual online encyclopedia, which was founded in 2001 and contains over 30 million articles.

Skype - software product, which is used to exchange text and voice messages online. The system also allows users to communicate with users of fixed and cellular networks, share files for free.

Blogger/Blogspot - a blogging service that allows users to create their own online magazine.

Facebook - the website of a very popular social network, which has more than 1 billion active users, was established in 2004, the site includes many additional programs that can be used effectively for educational purposes $[7$, p. $34-$ 40].

III. Web technologies using for the establishment of teaching materials, interactive exercises, tests, video materials, books for reading, personal achievements storage.

Web Technology - is a resource that helps teachers to realize certain educational goals being online, using all the functionality and tools of the Web space [2].

There are many benefits of Web2.0 / Web 3.0 technologies: accessibility, mobility, flexibility, unlimitedness, convenience and ease of use, speed of distribution, receiving and processing of information, feedback, communication settings, implementation of creative ideas, storage and systematization of important information, etc. 
ISSN 2078-5526. Вісник Львівського університету. Серія педагогічна. 2018. Випуск 33

We propose the selection of Web services for the foreign language studying by the primary school students, which will help teachers to realize the ideas by creating unique individual materials in the form of interactive exercises, games, tests and other didactic materials.

1. Service Web2.0 Learning Apps. Org (https://learningapps.org) is educational because it is designed to support studying and teaching processes with a help of small interactive modules that can be used directly as studying resources or for the individual work. The purpose of this service is an open library of independent blocks (exercises) creation, suitable for reuse and changes. Blocks (or exercises) are not included in the specific scripts or programs, so they are not considered as integral lessons or tasks, but as an opportunity to use [2].

2. Service Loupe (www.getloupe.com) gives teachers the opportunity to create cards that come to life, photo collages and games (2, fig. 4$)$. The service is free of charge, with an accessible and simple interface; all works are stored in the author's profile.

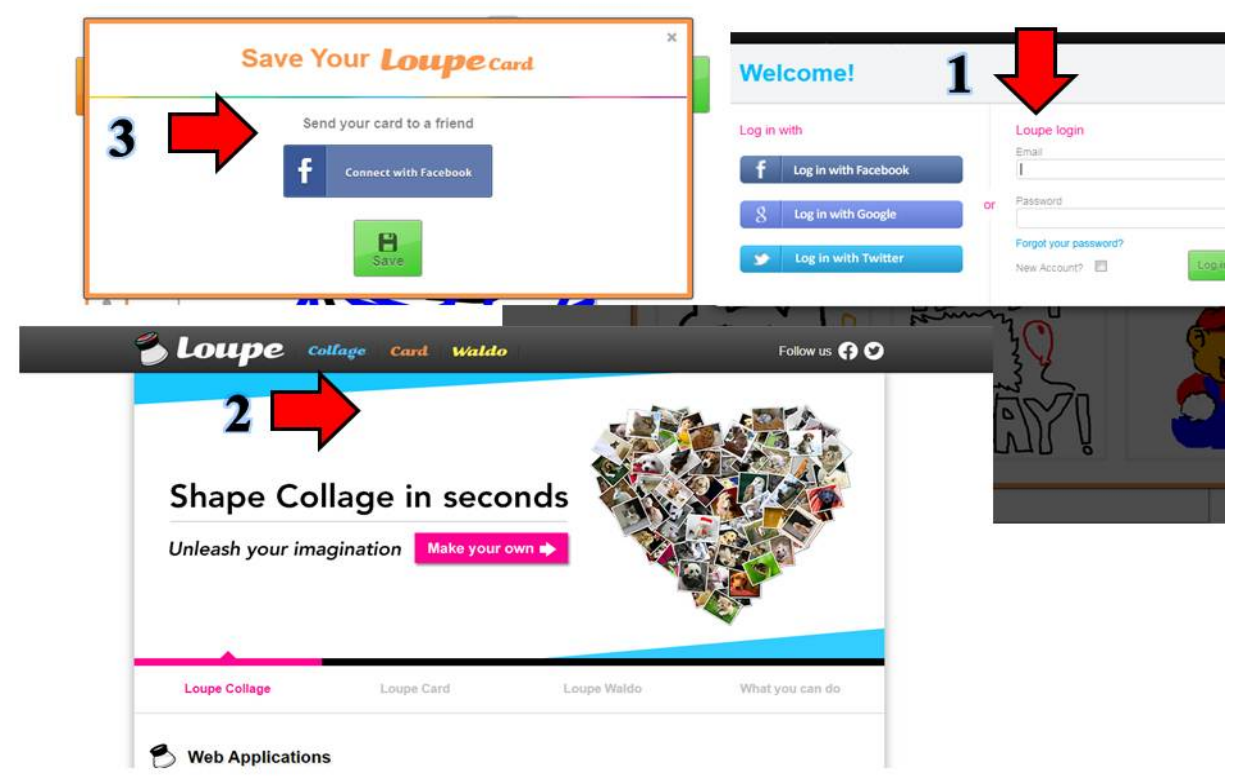

Figure 4. Fragments of windows of Loupe service

The user must register (1, Fig. 4) by filling in the registration form. Cards are easy to create, do not require a lot of time and professional skills. The teacher or children draw a particular object, the sequence of actions is written and reproduced by the program (4, Fig. 5) so "as it is coming to life".

The teacher can use cards in the process of: 
- introduction, studying, sounds and letters consolidation (for example, a letter appears and students should name and write words that begin with this sound (5, Fig. 5). http://www.getloupe.com/card/view/nqmbfs2jvus

- playing the game "Bingo", a vocabulary dictation, and other games (for example, gradually words appear on the screen, and students should cross them out on the previously prepared cards, write in a notebook, correct mistakes, etc. (6, Fig. 5)

- playing the game What's this? (For example, images appear gradually and students guess what it is, asking the teacher This is a ... ..? (4, Fig. 5)). In addition to the possibility of creating cards, teachers can also create a collage, as one of the interactive means of studying, repeating, consolidating, and lexical units applying. It is enough to select and download the image of the necessary objects, set the collage parameters and create a task (For example, students choose an image and name it, or the teacher names the word and the students look for the image) (7, Fig. 5). A teacher can involve students during a lesson or at home to create collages or cards and distribute this work in the social networks. (3, Fig. 4).

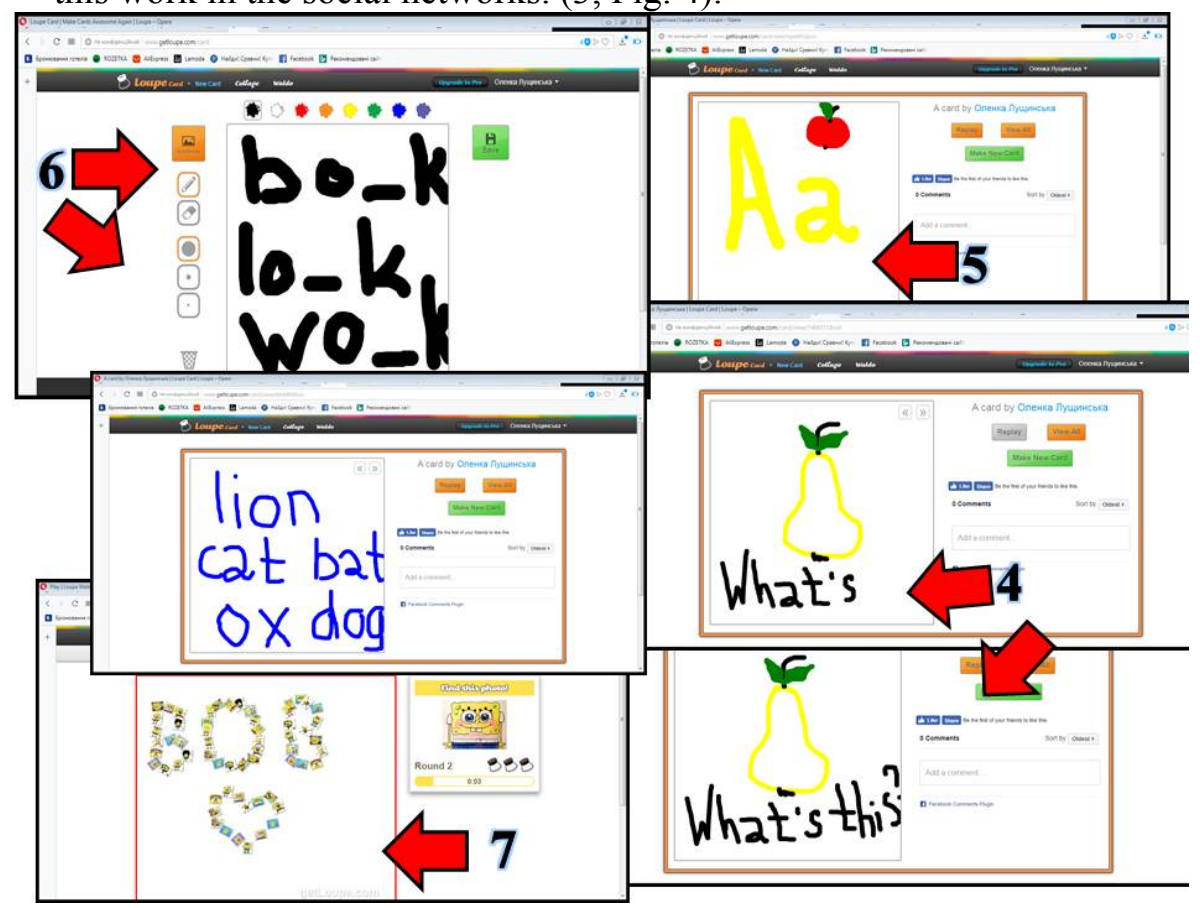

Figure 5. Examples of the exercises, developed with a help of Loupe Service

Kahoot (https://kahoot.com) - is one of the services for creating online quizzes, tests, exercises, and tests. Students can make tasks created by a teacher 
ISSN 2078-5526. Вісник Львівського університету. Серія педагогічна. 2018. Випуск 33

from any device (tablet, computer, phone) connected to the Internet. A teacher can create tasks using images or videos, and with the help of the appropriate tools to set time for the performance and evaluation of the test work. After registration (1, Fig. 6 ), the teacher can use the created by other users exercises, (in the search bar enter the subject, keywords (2, Fig. 6), select a test from the list, click "Play" (5, Fig. 7) then select the form of the exercise (6, Fig. 7) or create the personal tasks for the students' knowledge control (press "Create" - select the type ("Quiz", "Jumble", "Discussion", "Survey" (3, fig. 6) and fill in the necessary parameters (4, Fig. 6). To complete the tasks, the student must follow the link kahoot.it, enter the game code, provided by the teacher (7, Fig. 7), and his/her name in order to enter the teacher's profile. After registration of all the participants, the teacher clicks on "Start" (8, Fig. 7) and the students begin to work on a problem solving. Students read all the questions from the teacher's device (computers, interactive whiteboards, multimedia screen), choosing only geometric figure that corresponds to the selected answer option (9, Fig. 7). It is important that the evaluation has two parameters - the speed and the correctness of task accomplishment. The teacher can use the created tasks or involve the students to this work.

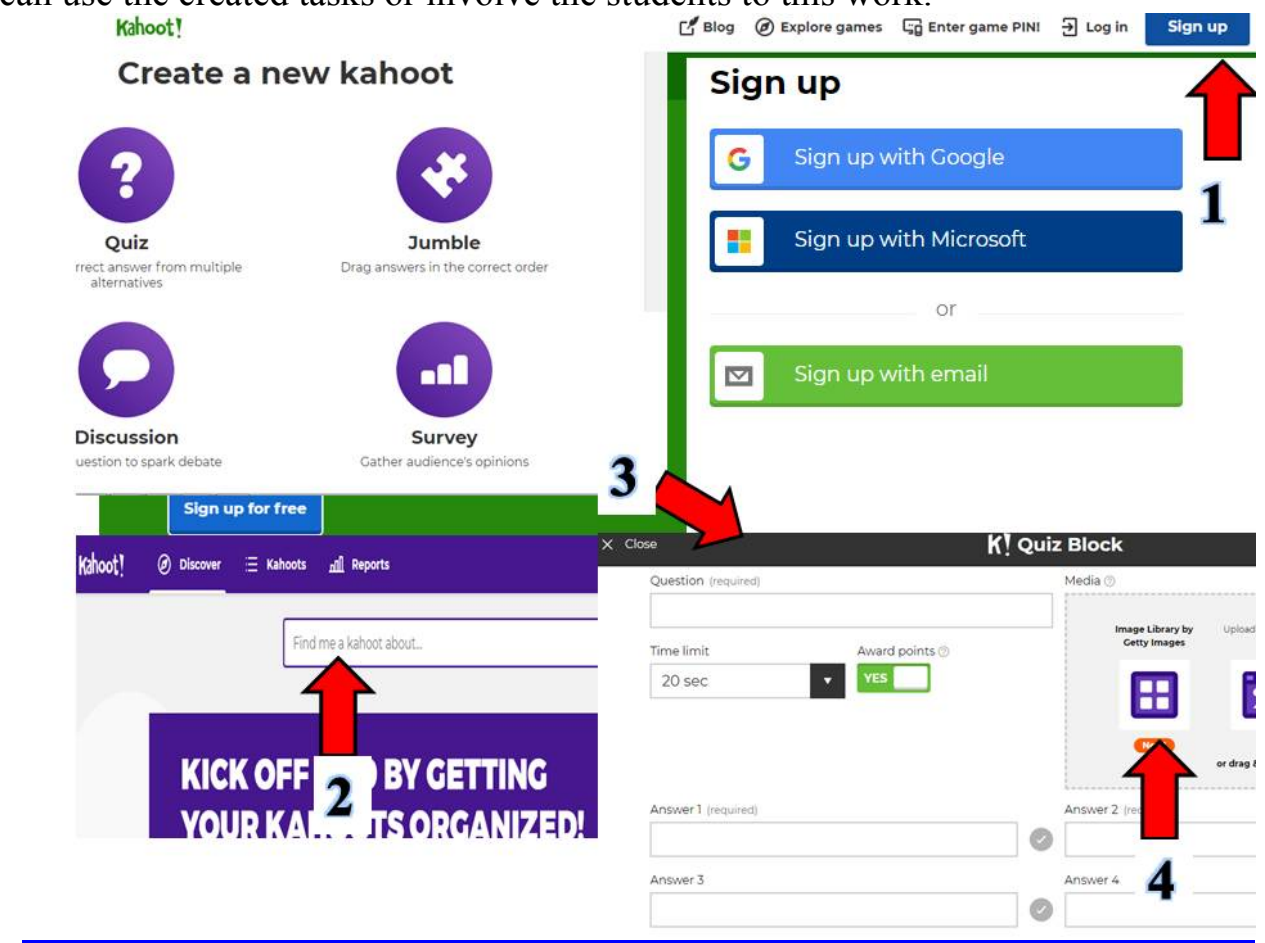

Figure 6. Service Kahoot 


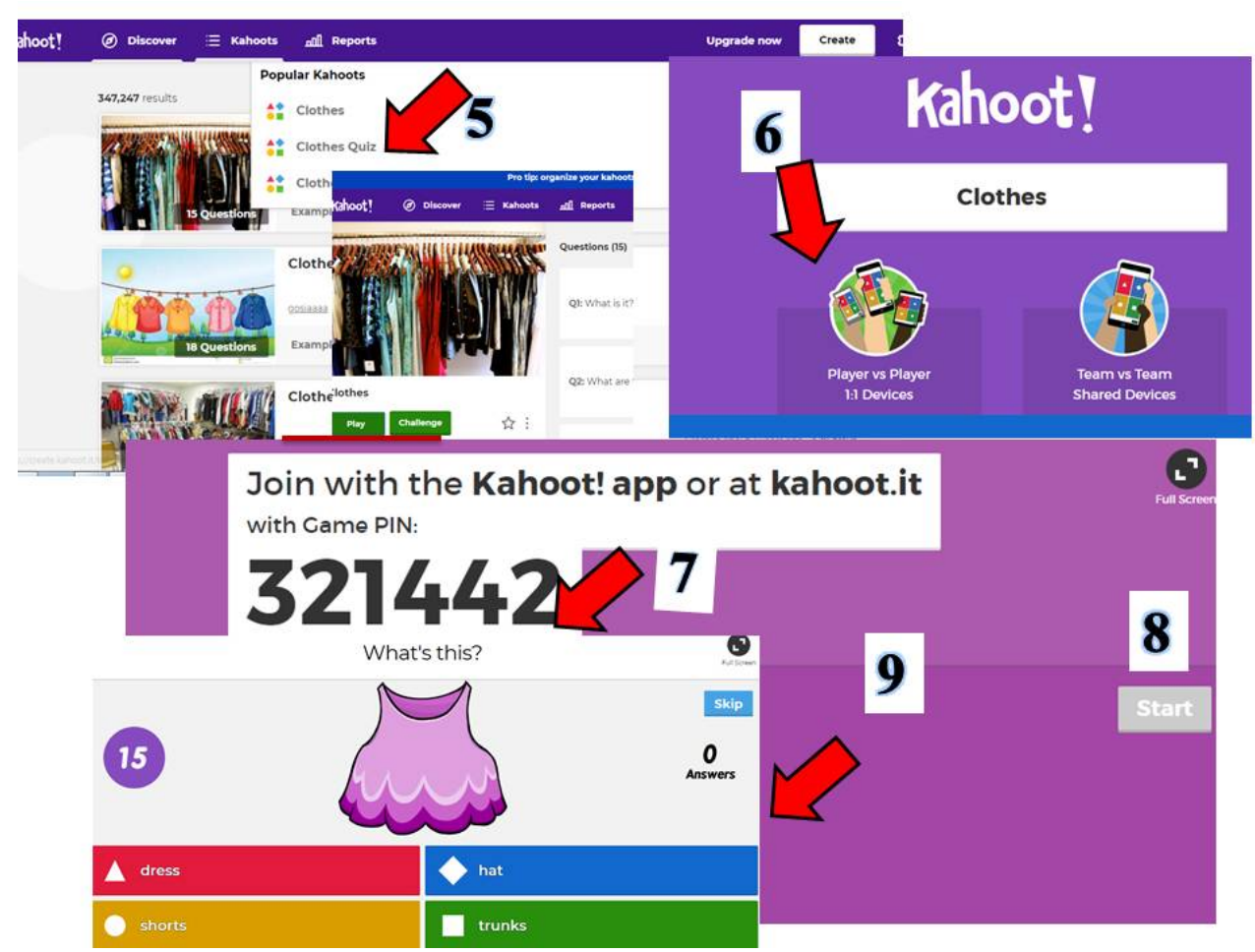

Figure 7. Work principles of Kahoot service

The service Tools for educators (https://www.toolsforeducators.com ) is easy to use, free of charge, has an accessible interface and a laconic structure of the menu. (1, Fig.8). The teacher can develop crossword puzzles, exercises, dominoes, board games from the suggested topics and resources. It is enough to choose the type of the task (2, Fig.8), topic, form and find the lexical units or images from the menu (3, Fig.8). After pressing "Make it" (4, Fig.8), the user receives an elaborated exercise that can be printed (5, Fig.8). Dominoes, board games, cubes and other exercises help to consolidate the acquired knowledge, skills and abilities, bring them to the level of automatism and organize the process of the foreign language studying. 


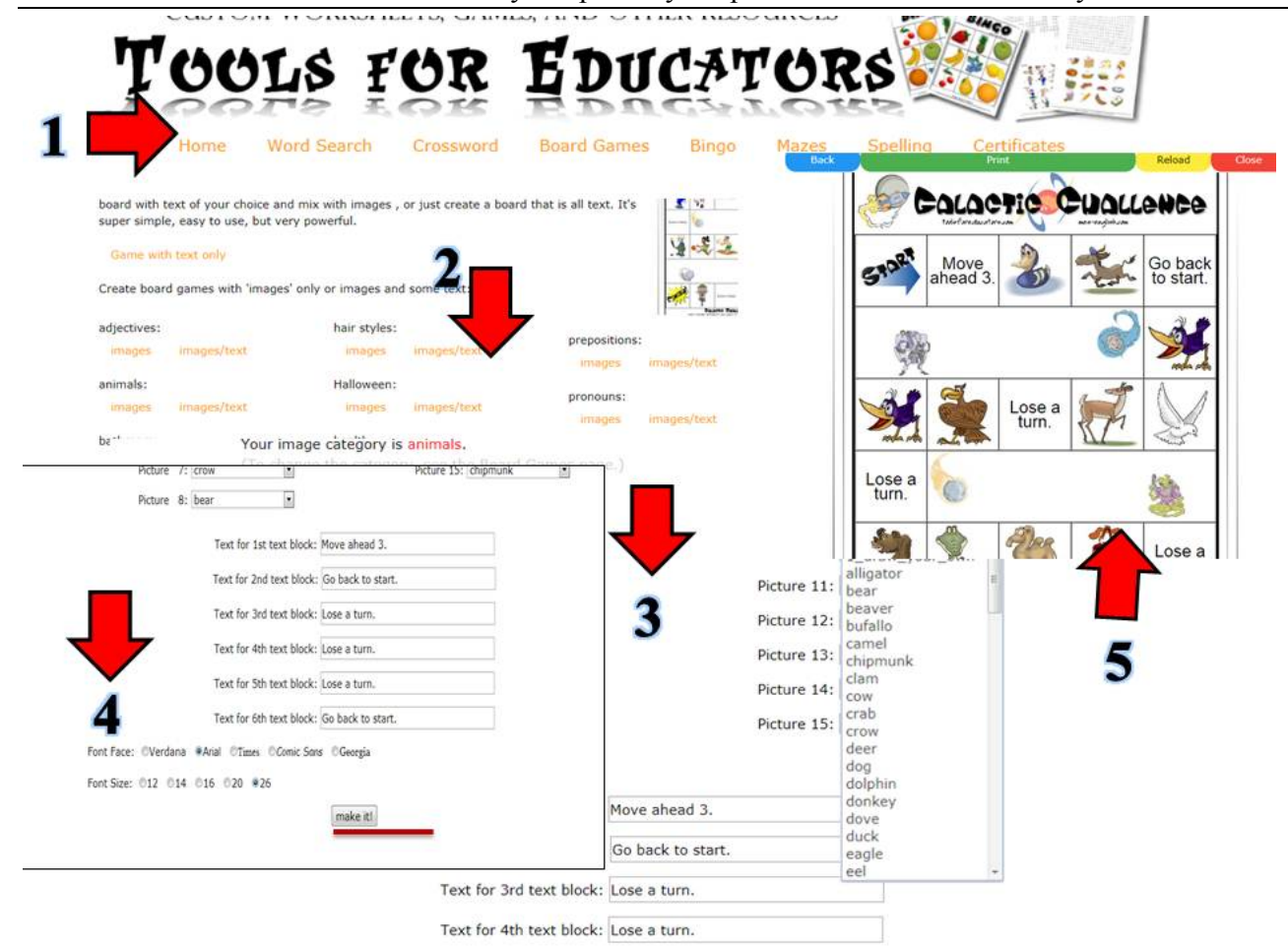

Figure 8. Service Tools for educators

Services for creating personal avatars that speak, in other words "talking pictures" are useful for studying. Two services can be used. The first service allows users to create their own Blabberizes (https://blabberize.com), using the selected images and downloaded to the service from the PC. Firstly, the user needs to create an account by filling in the registration form (1, Fig. 9). The user with a help of the available menu can create ("Make"2, Fig. 9) and view blabberizes, created by other users ("Browse" 3, Fig. 9) or his/her own blabberizes ("My stuff" 4, Fig. 9). To create a blabberize the user should press "Make", download the image (5, Fig. 9), set mouth area, using tools (6, Fig. 9), record sounds, using microphone or download the previously prepared audio file (7, Fig. 9) and save, adding the description (8, Fig. 9). You can view the created blabberize by a link (https://blabberize.com/view?id=1819354), in the user's profile or share with a help of the social services (9, Fig. 9).

The second service, which helps to create more realistic talking objects, is Voki (https://www.voki.com ). In order to create Voki the user should register by filling in the registration form (1, Fig.10), choose "Create" (2, Fig. 10), then the service will offer ready character patterns with the ability to change clothes, background, appearance $(4,5,6$, Fig. 10). To record a voice you need to click on 
the icon (7, Fig. 10) or add text for the voice recording. To complete the Voki creation process - press "Save" (8, Fig. 10). The user can view all created talking pictures in a private library "My Voki" (9, Fig. 10). In addition, the created works can be distributed with the help of the social services (10, Fig. 10). Teachers can use talking pictures for the purpose of sounding tasks from a fairy tale character, puzzles, speed boards, songs, stories or texts for listening, for dialogues creating.

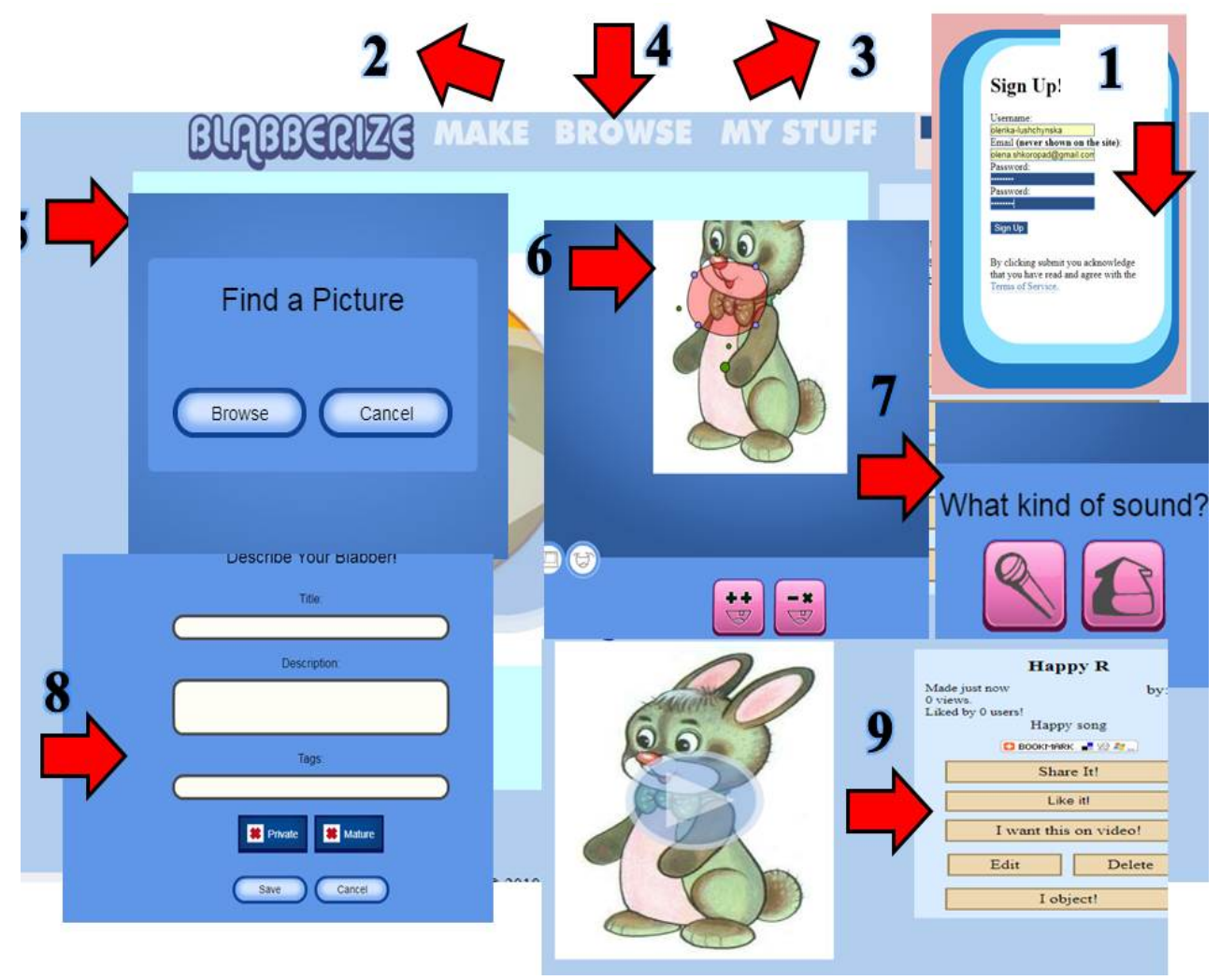

Figure 9. Service for «talking picture» creation, Blabberize 


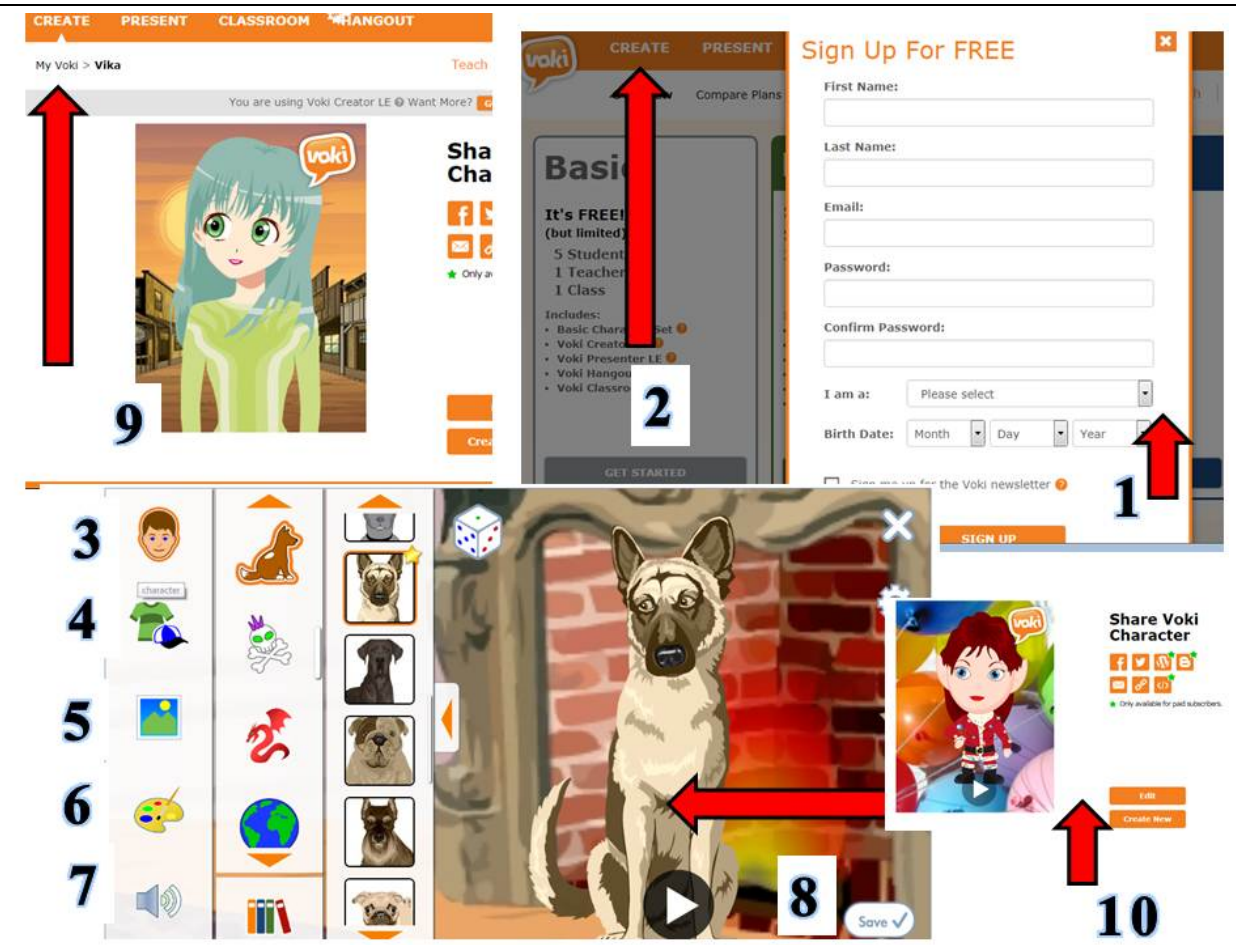

Figure 10. Service for «talking picture» creation, Voki

Service ThingLink (http://www.thinglink.com) gives the opportunity to create multimedia posters, which are charted with attached multimedia content markers. The e-poster provides educational material in the form of interactive elements (image, text), to which the following didactic materials are attached with a help of hyperlinks: text documents, graphic images, video and audio files, presentation materials, auxiliary teaching means, etc. The information for the student is presented not immediately, but opens depending on the user's influences: the teacher during the teaching of the educational material, the student in the process of the personal work [8]. The service supports the photo download, video, and sound from the popular hosts, such as YouTube, VimeoVideo, SoundCloud etc. Each marker is a separate link. The user must fill in the registration form (1, Fig. 11), then he will be able to develop personal interactive posters using all the features of the Web Resource. To create a multimedia poster the teacher should choose "Create" (2, Fig. 11), afterwards a workspace with all the necessary tools will appear. Each new link is presented as a label (3, Fig. 11), which changes to the link only when you hover over it. (4, Fig. 11). All created posters are stored in the user's account. This service helps to create didactic materials, technological schemes for a certain type of tasks, thematic collections of resources in the Internet 
and media collections, interactive posters for games, competitions, quizzes, journeys. Besides the Thing Link service there is a possibility to use Glogster (https://edu.glogster.com).

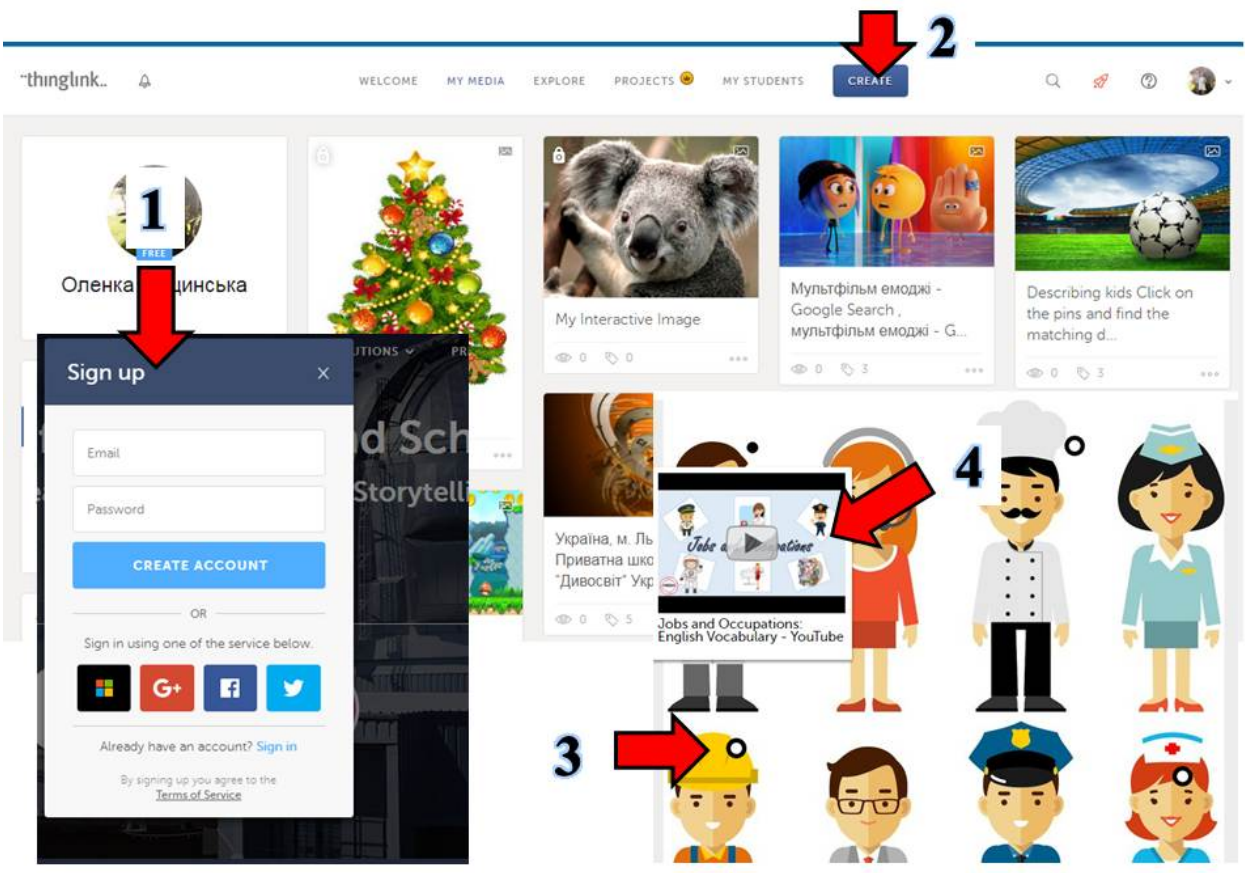

Figure 11. Fragments of windows of Thing Link service

Padlet (https://uk.padlet.com) is a tool for creating an online wall for the collaborative work. The user can add advertisement, news, download graphic images, multimedia files, links to Internet pages, make notes on the created board. The service is free, but it restricts the user to the number of created pages. The user needs to register (1, Fig. 12), then he can create padlets (2, Fig. 12) using various patterns of the attached information. All created padlets (3, Fig. 12) are stored in a user's account and can be hidden or protected from other users by a password. Padlets help teachers to systematize materials by the topics (4, Fig. 12), save the necessary links, attract students to search and add resources and communicate with parents.

According to N. Fominykh, the use of Internet technologies in English lessons has the following basic pedagogical goals:

- realization of social order caused by the informatization of modern society;

- humanitarization and humanization of the educational process; 
- intensification of all levels of the educational process;

- development of the student's personality, preparation for independent productive activity in the conditions of the information society [9, p. 24-26].

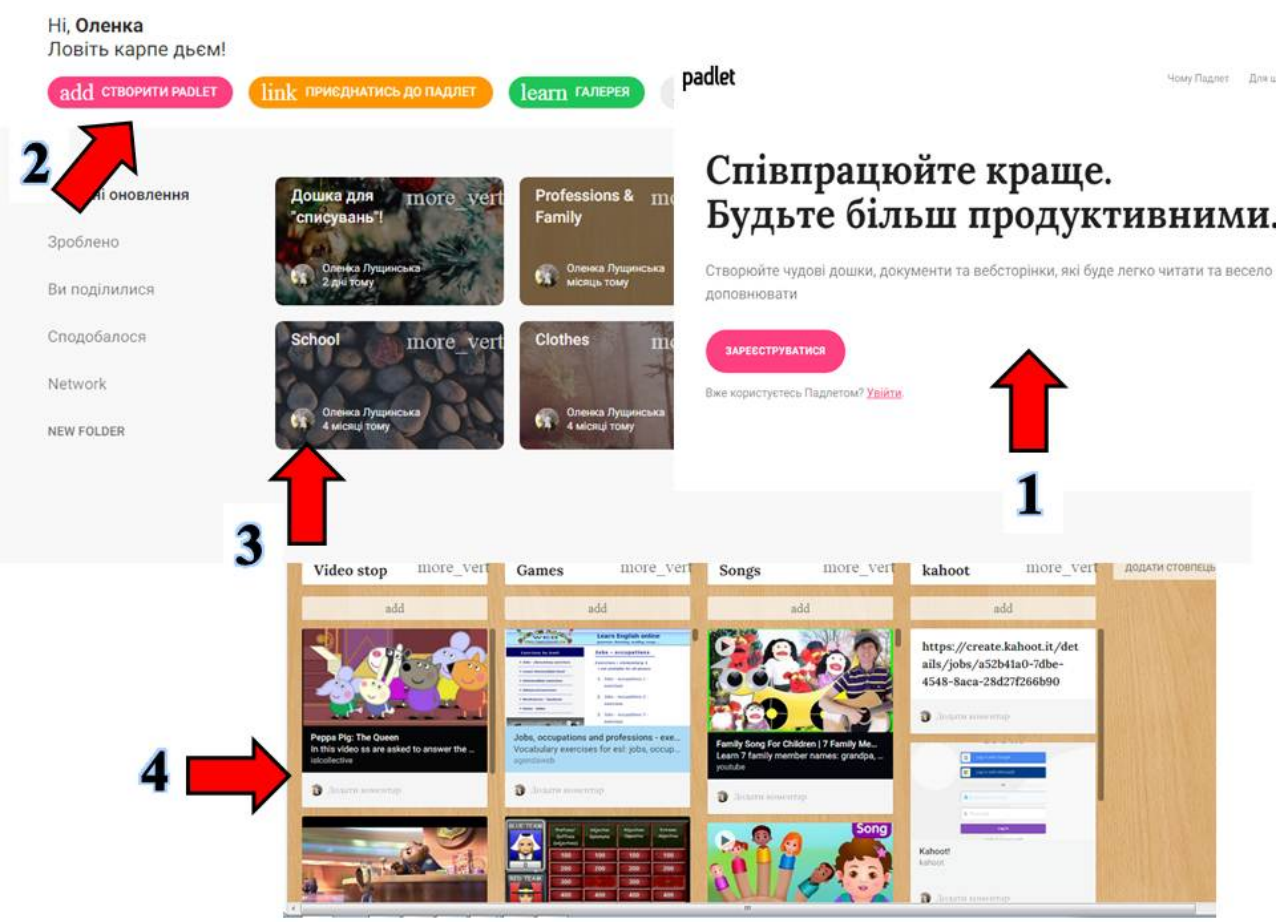

Figure 12. Service for the interactive board Padlet creation

\section{Using of Web sites, portals, pages with free content for a foreign language studying.}

Web site (from Eng. site - location, place) - is a combination of electronic documents and files in a network, which are connected by one domain name or IP address. In other words, a site is a place in the Internet, which is given to the user of this network for the placement of information: text, audio and video files, images, links, etc [10].

An important background for the formation of foreign language competence is the creation of a communicative environment which is as close as possible to the real. There are a lot of sites in the Internet space, the resources of which enable the teacher to organize the educational process as efficiently and interesting as possible. Some services offer exercises - Worksheets, visual dictionaries and cards - Flashcards, others - interactive exercises, audio and video materials. The teacher can use authentic exercises, videos, audio materials. In addition, the didactic 
materials will help to consolidate the knowledge gained from the topic studied by the primary school students. It is important that each teacher has a set of necessary resources.

We offer the selection of Internet resources for a foreign language studying.

One of the most popular video hosting services is YouTube. The use of the service in the process of the English language studying by the primary school students will contribute to the achievement of the studying objective, namely the formation of foreign language communicative competence, the development of skills of listening, speaking, reading and writing. You Tube is a social service, which offers video posting and storage services. The users can add, view and comment the video materials[10]. The service contains a variety of educational cognitive videos and offers both mono-thematic and plot-fable authentic texts. The visual support during the perception of songs, stories, tales, monologues and dialogues contributes to the positive result achievement in the process of listening skills improving. Introduction of the authentic pronunciation will contribute to the formation of phonemic hearing and the development of all types of competences. In the process of English teaching to primary school students, the teacher can use videos from such channels, as English Tree TV, Magic Box English ELS Kids Channel, English Singsing, Chu Chu TV, English lessons for children, DinoLingo, Super simple songs, which offer songs, cartoons, stories, fairy tales, examples from everyday life, dialogues built using lexical units, grammatical constructions or phonetic material [11, p. 35].

One of the interesting services is English Language Teaching Resources (https://www.englishwsheets.com). The teacher can find and download the necessary didactic materials (exercises, tests, flash cards, texts for reading), which are divided into three sections (1, 2, 3, Fig. 13): Reading (texts for reading), Vocabulary (exercises and visual dictionaries by topics), Grammar (activities on grammar skills formation). When the topic has been chosen, the user can choose exercises, offered by the service, view or download them (4, Fig. 13). This site is easy to use, free of charge; there is no need to register. 


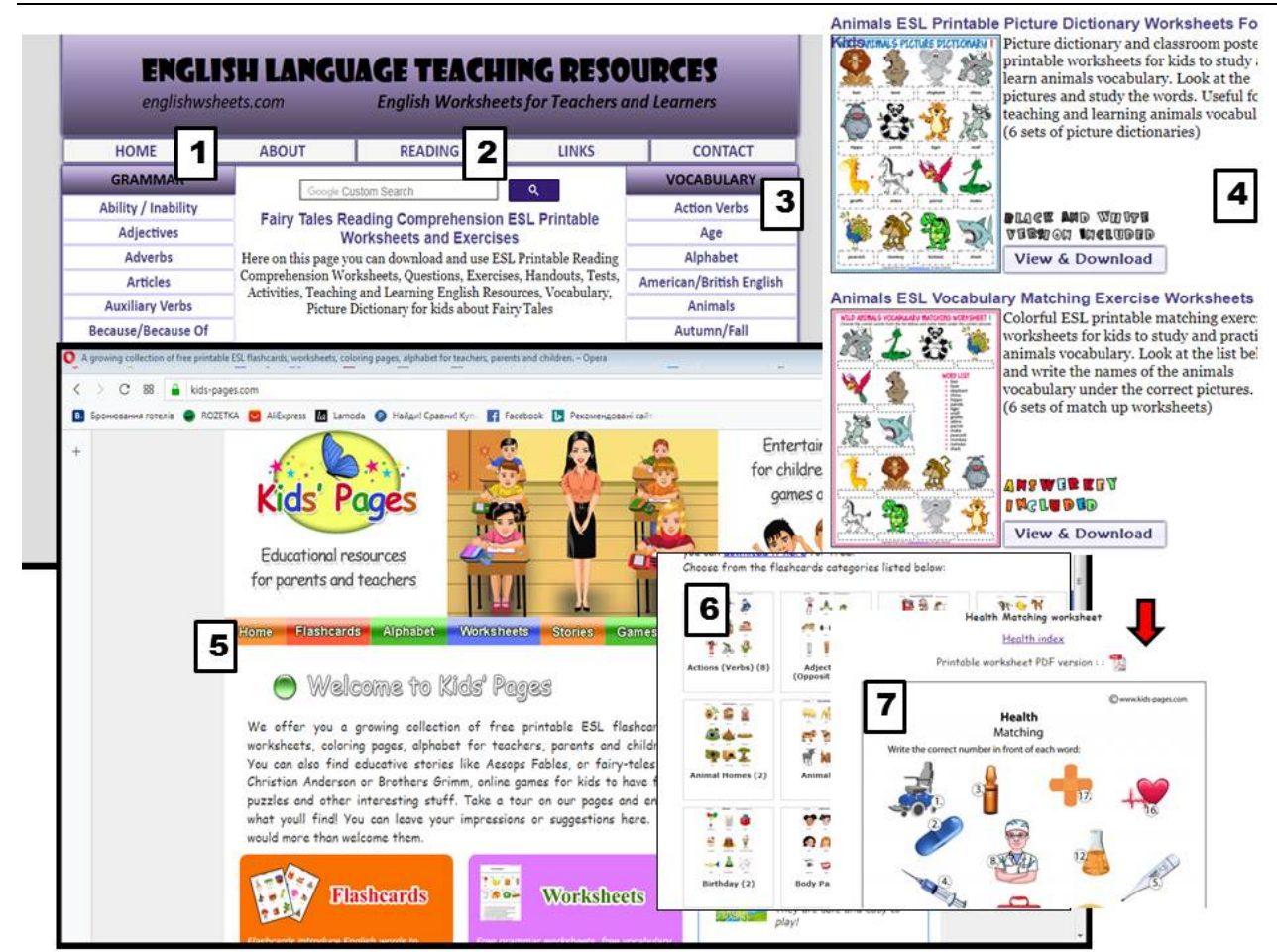

Figure 13. Sites English Language Teaching Resources and Kids' Pages

With a help of the service Kids' Pages( http://www.kids-pages.com) teachers can find freely available games, rhymes, visual dictionaries, exercises, texts for reading, reading cards, tasks for learning the alphabet, colorations (5, Fig.13). All materials are divided into themes, after pressing the necessary section or exercises the teacher can view and download them in Pdf format (6,7, Fig. 13). The similar service ESL-Kids (http://esl-kids.com) contains materials for primary school students teaching, including flash cards, exercises, interactive games and songs for children. The official site of the British Council will be a very useful resource for the English teacher. (https://learnenglishkids.britishcouncil.org).

An interesting service with a selection of interactive games - Games to Learn English (https://www.gamestolearnenglish.com) can be used both online and without the access to the Internet. The base of interactive games to consolidate the material can involve all the participants in the educational process. The users can play games online and download them on a personal computer. The service is easy to use, free of charge and does not require the personal profile creation.

The site iSLCOLLECTIVE (https://en.islcollective.com) contains many didactic materials for English lesson organization, which teachers can download and print (1, Fig. 14), video-stops (2, Fig. 14), as well as gives the possibility of 
cooperation, teachers can share their personal experience. The user needs to register in order to use all the features of this site. All materials are divided into lexical and grammatical, sorted according to the type (exercise, game, board game, domino, etc.) and according to the English language proficiency (beginning, low intermediate, intermediate, high intermediate) (4, Fig. 14). The teacher can view the task and then download it in the format doc after setting the required search parameters.

ESLvideo belongs to the services, which include tests for understanding the content of the authentic video and audio fragments; it also allows to create your own tests based on files hosted within other services. All video tests, stored in ESLvideo, are programmed according to the English language proficiency (beginning, low intermediate, intermediate, high intermediate), which makes searching of the required test quick and easy. This service allows you to create tests to the video file according to your own needs. First of all you have to register (fast and for free), go to the tab "Create a quiz", where the special form for the video test creation will open; choose video for the test creation on the YouTube site or other video hosts. The user needs to copy the video code on the page with the necessary video (video embed code) in the appropriate field in the form. Then the user has to fill in the appropriate fields with the questions to the video, mark the correct options so that the service could independently count the number of correct answers), add notes (optional) and save the completed video test. In order to view it the user should go to the tab "My Account" [12].

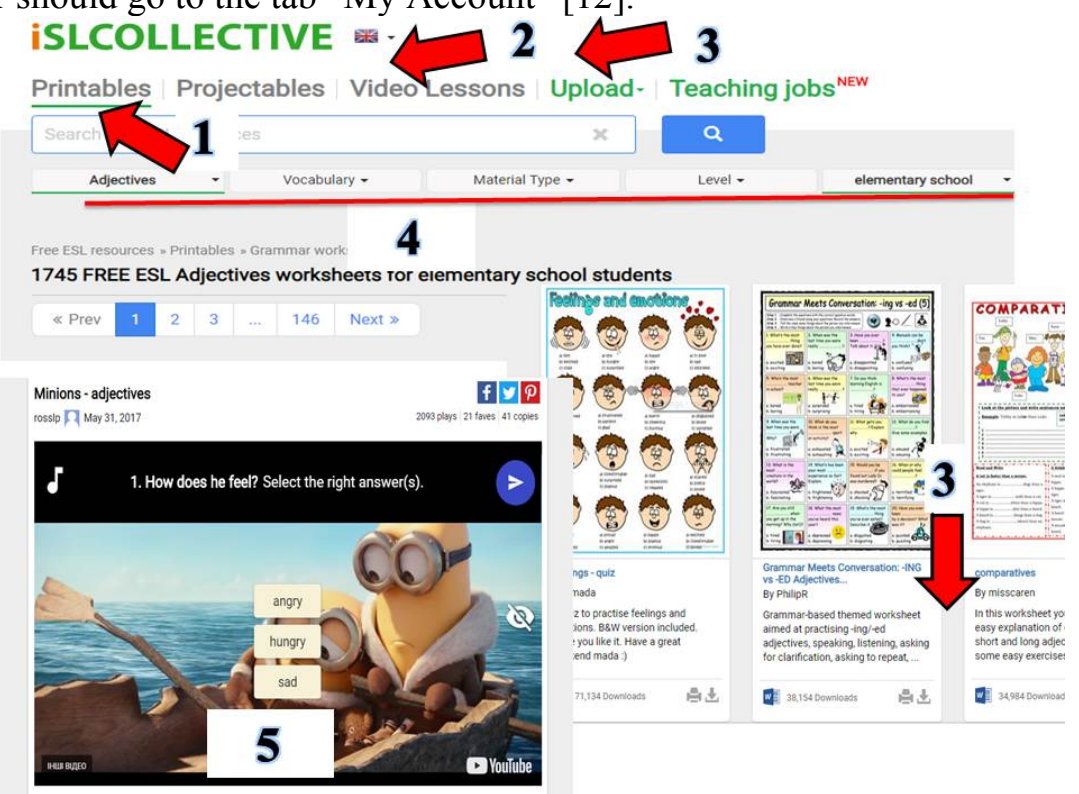

Figure 14. Site iSLCOLLECTIVE 
The site Agenda Web (https://agendaweb.org) offers users a huge base of didactic materials, interactive exercises, video materials, audio, authentic texts, dialogues, fairy tales, and interactive books. All the materials are divided according to the English language proficiency and are free of charge. Teachers can use the necessary materials online on each stage of the foreign language lesson. O. Lushchynska's teaching experience confirms the fact that the use of interactive exercises contributes to the formation of foreign language competence and sustainable motivation in primary school students in the process of the foreign language studying.

Information and communication technologies in the foreign language studying are undoubtedly of great practical importance, as follows:

cosit is an effective means of educational material visualization; gives the teacher the opportunity to realize his/her creative potential;

cshelps the teacher to implement a learner-centered approach; coscontributes to the personal enrichment and acculturation; cosit is a means to increase motivation to the subject studying;

cosstimulates the search activity of the student and develops his/her creative abilities [6].

The use of ICT in the studying process, computer support in English teaching allows to make the teacher's work utterly new, contributes to an interesting and more comprehensive material explanation, clear presentation of even rather sophisticated educational material, consequently contributes to a significant reduction of the practicing time for the successful topic acquisition.

The above-mentioned services contribute to the dealing with troubles while reading or speech units recognition, as well as promote quality English acquisition by the primary school students.

The use of sites with interactive games, exercises in the process of English studying by the primary school students contributes to the formation of receptive and productive forms of speech activity.

Therefore, the use of ICT in the process of formation of foreign competence contributes to the development of language, speech, socio-cultural and sociolinguistic competencies, the development of creative and critical thinking, the acquisition of spontaneous speech, the formation of motivation of the primary school students to study English.

The search of the new Web technologies and attracting teachers to their active use will be the prospects for the further researches.

1. Lushchynska $O$. Information and Communication Technologies: Modernity and Prospects. Całożyciowe uczenie i stawanie się: perspektywa 
teoretczno-praktyczna / redakcja naukowa: Chabior A., KrawczykBlicharska M., Kowalski S. Kielce: Wydawnictwo Uniwersytetu Jana Kochanowskiego, 2018. P. 71-81.

2. Лущиинська O. Перспективи використання Інтернет-технології у навчально-виховному процесі початкової школи // Науковий вісник Мелітопольського державного педагогічного університету імені Богдана Хмельницького. - Cep. Педагогіка, 2017. URL: http://ojs.mdpu.org.ua/index.php/nv/article/view/1919/2530

3. Свірепчук I. A. Застосування сервісів Web 2.0 в навчанні англійської мови. URL: http://www.kamts1.kpi.ua/sites/default/files/files/svirepchukzastosuvannya.pdf

4. Кадемія М. Ю. Інформаційно-комунікаційні технології в навчальному процесі / Кадемія М. Ю., Шахіна І. Ю. // Навч. посіб. - Вінниця: ТОВ “Планер", 2011. - 220 с.

5. Гуревич $P . C$. Інформаційні технології навчання: інноваційний підхід: навчальний посібник / Р. С. Гуревич, М. Ю. Кадемія, Л. С. Шевченко. - Вінниця: ТОВ “Планер”, 2012.

6. Чумак $B$. B. Інформаційно-комунікаційні технології в навчанні англійської мови.

URL: http://osvita.ua/school/lessons summary/edu technology/47521/.

7. Блощинський I. Г. Огляд можливостей використання соціальних сервісів у процесі вивчення іноземної мови / І. Г. Блощинський, Д. В. Таушан, I. А. Яремчук // Збірник наук. пр. Національної академії державної прикордонної служби. - Серія: Педагогічні та психологічні науки. - Вип. 3. C. 31-43.

8. Таблер T. I. Сучасний дидактичний засіб - електронний інтерактивний плакат. дежим доступу: http://virtkafedra.ucoz.ua/el_gurnal/pages/vyp14/Tabler.pdf.

9. Фоміних Н. Ю. Інформаційно-комунікаційні технології у викладанні філологічних дисциплін: навчально-методичний посібник. - Севастополь: Рібест. - 2010. - 196 с.

10.Олійник T. I. Інтернет-технології у навчанні старшокласників англійської мови / Т. І. Олійник, В. Ю. Афанасьєва. - 2013. Режим доступу: http://visnyk.chnpu.edu.ua/?wpfb $\mathrm{dl}=1132$.

11.Salaberry M. R. The Use of Technology for Second Language Learning and Teaching: A retrospective / M.R. Salaberry // Modern Language Journal. 2001. - №85(i). - P. 30-6.

12.Свірепчук I. A. Застосування сервісів Web 2.0 в навчанні англійської мови. Режим доступу: http://www.kamts1.kpi.ua/sites/default/files/files/svirepchuk-zastosuvannya.pdf. 
ISSN 2078-5526. Вісник Львівського університету. Серія педагогічна. 2018. Випуск 33

Стаття: надійила до редколегії 28.08.2018

доопрацьована 11.11.2018

прийнята до друку 05.12.2018

\title{
ВИКОРИСТАННЯ ІНФОРМАЦЙНО-КОМУНІКАЦІЙНИХ ТЕХНОЛОГІЙ У ПРОЦЕСІ ВИВЧЕННЯ АНГЛІЙСЬКОЇ МОВИ ЗДОБУВАЧАМИ ПОЧАТКОВОЇ ОСВІТИ
}

\author{
Олена Лущинська \\ Львівський національний університет імені Івана Франка, \\ вул. Туган-Барановського, 7, Львів, Україна, 79005
}

Стаття присвячена опису теоретико-практичних аспектів використання інформаційно-комунікаційних технологій у процесі вивчення англійської мови учнями початкової школи. У вступі автор окреслює актуальність досліджуваної проблеми, визначають суперечливі аспекти організації освітнього процесу в початковій школі, що не забезпечують належного використання інформаційнокомунікаційних технологій у практиці роботи вчителя початкової школи.

Означена мета статті - проаналізувати можливості використання інформаційно-комунікаційних технологій у процесі вивчення англійської мови учнями початкових класів - розкривається за допомогою сукупності добору матеріалів та методів викладу матеріалу (аналіз теоретичних наукових розвідок вітчизняних і зарубіжних дослідників, емпіричне дослідження стану використання інформаційно-комунікаційних технологій учителем початкової школи та інтерпретація отриманих результатів, візуалізація теоретико-методичних матеріалів дослідження, конкретизація інтернет-сервісів, системний аналіз комплексного вивчення означеної проблеми).

У статті чітко описано інтернет-сервіси, які пропонують автори для вивчення іноземної мови учнями початкової школи (You Tube, English Language Teaching Resources, Kids' Pages, ESL-Kids, Games to Learn English, iSLCOLLECTIVE, ESLvideo, Agenda Web, Tools for educators, Web2.0 Learning Apps. Org, Loupe); означено, що застосування інформаційно-комунікаційних технологій у вивченні іноземної мови, має велике практичне значення (у статті конкретизовано можливості, які реалізуються в освітньому процесі початкової школи).

Окреслений висновок та перспективи дослідження відображають логічний зв'язок означеної проблеми 3 наступними науковими розвідками, визначають органічне поєднання теоретичних здобутків з необхідністю пошуку шляхів для їх практичного застосування.

Ключові слова: інформаційно-комунікаційні технології, англійська мова, здобувачі початкової освіти. 